\title{
The Mediating role of Firm Innovativeness in the Relationship between Knowledge Sharing and Customer Satisfaction in SMEs
}

\author{
Anna Michna \\ Silesian University of Technology \\ 26 Roosevelta st., 41-800 Zabrze, Poland \\ E-mail.anna.michna@polsl.pl \\ cross $^{\text {ref }}$ http://dx.doi.org/10.5755/j01.ee.29.1.19027
}

\begin{abstract}
Customer satisfaction, innovativeness and knowledge sharing have fundamental meaning for contemporary managers and draw the attention of both researchers and practitioners. However, the relationships between these constructs are less than evident in prior empirical research focused on small and medium-sized enterprises (SMEs). To fulfil the research gap, this study integrates separate research streams and empirically tests the relationships between these constructs in Polish SMEs. Based on the sample of 120 firms and using PLS-PM technique, it was found that knowledge sharing and firm innovativeness are significant and positively related to customer satisfaction. Knowledge sharing and a firm's innovativeness predict $29.9 \%$ of the variability of customer satisfaction indicators. Moreover, firm innovativeness partially mediates the relationships between knowledge sharing and customer satisfaction. This finding supports suggestion that effective knowledge sharing improves a firm's ability to introduce new or improved products and services, which in turn increase customer satisfaction. Results of this study provide empirical evidence for the importance of knowledge sharing for firm innovativeness and customer satisfaction. The focus on SMEs in a single country, subjective nature of the data and cross-sectional design of the research are the main limitations of this study.
\end{abstract}

Keywords: Customer Satisfaction; Knowledge Sharing; Innovativeness; SMEs; Poland.

\section{Introduction}

Customer satisfaction is one of the most critical issues facing contemporary managers. It is claimed to be vital for a firm's success in today's competitive marketplace (Haverila \& Fehr, 2016) and treated as a strategic goal for most firms (Lee \& Lee, 2013). Many researchers have attempted to identify consequences of customer satisfaction. Customer satisfaction has been found to positively impact customer loyalty (Castaneda 2011; Demirci Orel \& Kara, 2014; Belas \& Gabcova, 2016; Diaz 2017; Kasiri et al., 2017), and customer repurchase intentions (Blut et al., 2015). Satisfied customers establish long term relations with firms, spread positive words, lead to successive repeating purchases, and are more likely to accept increases of prices (Anderson et al., 1994; Homburg et al., 2005). In consequence, customer satisfaction is expected to be correlated with a firm's profitability (Anderson et al., 1994; Helgesen 2006).

Because there is a general consensus among researchers and practitioners on the importance of satisfaction for a firm's performance, researchers have attempted to identify variables which have a positive effect on customer satisfaction. For example, they suggest that customer satisfaction is related to the organization's ability to develop and implement a process that will ensure a constant and timely delivery of quality products or services (Dongmo \& Onojaefe, 2013). Moreover, customer satisfaction is affected by employees' behaviors and their level of competence, support, friendliness, and courtesy (Gloor et al., 2017). However, this paper is focused on the role of knowledge sharing and firm innovativeness for customer satisfaction. The link between knowledge sharing, firm innovativeness and customer satisfaction may be perceived to be so self-evident that the relationship is often taken for granted. Nevertheless, no studies have examined these fundamental relationships in an integrated way with regards to small and medium-sized enterprises (SMEs). Previous empirical studies suggested links between knowledge sharing and customer satisfaction (Gupta, 2008, Supyuenyong \& Swierczek, 2011) or between firm innovativeness and customer satisfaction (Luo \& Bhattacharya, 2006; Kibbeling et al., 2013). However, the question about simultaneous impact of knowledge sharing and firm innovativeness on customer satisfaction in SMEs has yet to be answered definitively.

This study responds to previous calls for more research on marketing knowledge and knowledge management in SMEs in emerging markets. Theoharakis \& Hooley (2008) indicated that customer orientation and organizational innovativeness may play out differently in New versus Old Europe and "generalizability of marketing knowledge should also be tested in emerging markets" (p. 69). Zieba \& Zieba (2014) stated that there is still little known about knowledge management and innovation practices in SMEs in Poland and this area of research remains underexplored.

As Krajnakova et al. (2015) indicated, small firms can overcome resource constraints through generating competitive advantage by attaining customer satisfaction. In contrast to large enterprises, SMEs have usually limited manpower, knowledge and finance resources, narrow customer base, myopic strategic focus, and low bargaining power (Hudson et al., 2001; Michna et al., 2017). On the other hand, SMEs are characterized by flexibility, 
dynamism, creativity, quick reaction to customers' needs and ability to express personal touch (Krajnakova et al., 2015), which can be beneficial for customer satisfaction.

Thus, the purpose of this study is to explore a research question: what are the effects of knowledge sharing and firm innovativeness on customer satisfaction in SMEs? The research method applied to achieve the purpose of this study is a quantitative research analysis based on 120 valid questionnaires obtained from Polish SMEs.

The paper is organized as follows. First, the concepts of customer satisfaction, knowledge sharing and innovativeness are defined. Then, four hypotheses are developed and stated. Further, the methodology of empirical study is explained. In the next section results are provided. Finally, the discussion and conclusions are presented.

\section{Conceptual Development and Hypotheses}

The concepts of customer satisfaction, knowledge sharing and innovativeness

According to many researchers, customer satisfaction is the subjective customers' perception of a product or service. Oliver (1997) defined satisfaction as "a judgment that a product or service feature, or the product or service itself, provided (or is providing) a pleasurable level of consumption related fulfilment, including levels of underor over-fulfilment" (p. 13). More recently, Kotler et al. (2009) proposed the following definition of satisfaction: "a person's feelings of pleasure or disappointment resulting from comparing perceived performance or outcome in relation to his/her expectations" (p. 868). Customer satisfaction can be also defined "as the result of a cognitive and affective evaluation, where some comparison standard is compared to the actually perceived performance" (Srivastava \& Sharma, 2013, p. 276). A customer is satisfied when the perceived performance meets or exceeds expectations. On the contrary, a customer is dissatisfied when the perceived performance is less than expected. Three states of consumer satisfaction are distinguished by disconfirmation theory presented by Oliver et al. (1997). Positive disconfirmation occurs if the product or service is better than expected, negative disconfirmation if they are worse than expected, and simple confirmation if they are as expected. Moreover, as Spreng et al. (1996) noted, feelings of satisfaction arise when consumers compare their perception of the performance of a product or service not only to their expectations, but also to their desires. The literature differentiates between transaction-specific satisfaction and cumulative satisfaction (Homburg et al., 2005), although the latter is believed to provide a more accurate value of a customer's attachment for future consumption of a product or service (Lee \& Lee, 2013).

Knowledge sharing in a company is one of the knowledge management processes and is viewed as a behavior when an employee disseminates his/her acquired valuable knowledge to other employees within an organization (Ryu et al., 2003). Knowledge sharing reflects the willingness of employees to share both tacit and explicit information with their fellow co-workers (Serenko \& Bontis, 2016). That willingness depends on the organizational climate, including a high level of trust and employees' feeling that sharing knowledge is rewarding (Gupta, 2008). Knowledge sharing involves both collecting (receiving) and donating (disseminating) knowledge (Lin, 2015). In the knowledge sharing process, knowledge held by an individual is "converted into a form that can be understood, absorbed, and used by other individuals" (Ipe, 2003 , p. 341). In this process variety of means may be used: social networks (e.g. networking, get-togethers, organized social events), formal and informal meetings (e.g. mentoring and training sessions), and dialogue (Yang, 2009). Knowledge sharing attracts research attention because it is believed to have a positive effect on organizational competitiveness, innovativeness and economic performance (Andreeva \& Kianto, 2012; BenitoBilbao et al., 2015; Gunu \& Ajayi, 2015; Nawrocki \& Jonek-Kowalska, 2016). The concept of innovativeness can be considered at several levels: products/services, individual and organizational. However, this study is focused on the organizational level of innovativeness. In this perspective and for the purpose of this study, innovativeness is viewed as firm's both capacity and propensity to introduce innovation in the organization, i.e. new processes, products, or ideas (Lumpkin \& Dess, 1996; Hult et al., 2004). Capacity means that a firm has appropriate resources (e.g. management, knowledge, and finance resources) to introduce innovations, whereas propensity means that a firm is interested in and willing to introduce innovations. Hence, in this view the number of introduced innovations reflects a firm's innovativeness.

The relationship between knowledge sharing and customer satisfaction

It is widely accepted that acquiring new customers is more costly than retaining existing ones (Hennart, 2014), therefore managers should maintain or even improve customer satisfaction and loyalty. As mentioned before, customer satisfaction is related with quality of services and products. Steward (2008) noticed that employees' interaction with the customer is a critical component of customer satisfaction because a well-informed salesperson who shares knowledge with other employees is able to identify and locate in the organization resources needed for customers and meet customers' needs. It is also important to note that quick response to customer problems increases customer satisfaction (Gloor et al., 2017). Hence, sharing knowledge between employees increases the stock of knowledge of employees who are responsible for contacts with customers, which leads to more professional customer service. Moreover, knowledge gathered from customers and shared between employees and various departments can be used to provide new or customized products and services in response to new and changing customers' needs, expectations and preferences (Lin, 2015). In empirical research, Gupta (2008) found correlation between knowledge sharing and customer satisfaction. Similarly, Supyuenyong \& Swierczek (2011) found that in SMEs knowledge dissemination influences customer satisfaction. Based on the above discussion, the following hypothesis was formulated: 
Hypothesis 1. Knowledge sharing is positively related to customer satisfaction in SMEs.

The relationship between knowledge sharing and innovativeness

The critical role of knowledge for introducing innovation is emphasized in the extant literature. As Luo \& Bhattacharya (2006) indicated, a firm's innovativeness reflects a firm's ability to apply its internal knowledge stock to produce new technology and new products/services. Knowledge is embedded in different individuals and it needs to be shared in a firm by employees to establish new routines and mental models (Chen et al., 2010). Sharing knowledge between employees and different departments in an organization contributes to collective learning and synergistic benefits, reduces redundant learning efforts and improves the stock of knowledge available to the firm, which has a positive impact on a firm's innovativeness (Lin, 2007; Chen et al., 2010). As Liua \& Phillips (2011) noticed, in any interdependent work process an employee is not able to introduce innovation alone, but only by cooperation between individuals and combining their complementary knowledge, skills and perspectives can innovation process be carried out to its fullest potential. Therefore, firms with an effective knowledge sharing mechanism among employees are likely to be more innovative. With some exceptions (e.g. Darroch \& McNaughton, 2002), previous empirical studies confirmed the significant and positive linkage between knowledge sharing and innovativeness (Lin, 2007; Chen et al., 2010; Gunu \& Ajayi, 2015). Therefore, it is proposed:

Hypothesis 2. Knowledge sharing is positively related to innovativeness of SMEs.

The relationship between innovativeness and customer satisfaction

Innovative products and services can help firms to satisfy customers' constantly changing needs and demands (Sok et al., 2016) and customer satisfaction is perceived as the most important customer-related performance indicator for product innovativeness (Stock, 2011). Moreover, according to executives, customer satisfaction is one of the main outcome variables of innovation success (Boston Consulting Group, 2009).

As Stock (2011) noted, firms introducing innovations can signal their ability to satisfy current and future customers' needs, and innovative products increase customers' expected utility and satisfaction. Increased expected utility associated with innovations has a positive impact on customers' attitudes. On the other hand, greater innovativeness of products or services may negatively affect customer satisfaction. Customers may become overwhelmed and discouraged by the complexity of new products or services which may be too challenging for them (Calantone et al., 2006). Lack of information about new products and a larger number and variety of offered innovative products may lead to a rise of customers' uncertainty about the firm's ability to fulfil their needs and a decrease of customer satisfaction (Stock, 2011).
Empirical research generally indicates the positive relationships between innovativeness and customer satisfaction (Luo \& Bhattacharya, 2006; Stock, 2011; Kibbeling et al., 2013), although lack of correlation between these constructs was also found (Homburg \& Stock, 2004).

Because, as Stock (2011) noticed, empirically grounded research on the relationships between innovativeness and customer satisfaction is scarce and provides mixed results, further studies on this relationship are needed. As a consequence, in this study the following hypothesis is proposed:

Hypothesis 3. A firm's innovativeness is positively related to customer satisfaction in SMEs.

The mediating role of innovativeness for the relationship between knowledge sharing and customer satisfaction

Beside a direct relationship between knowledge sharing and customer satisfaction, an indirect relationship, through innovativeness, should be considered. As mentioned before, knowledge is a crucial input in the innovation process and effective knowledge sharing facilitates fostering innovation. Moreover, new or improved products and services are expected to increase customer satisfaction. For example, knowledge and experience with customers is gathered by the marketing department. Then this knowledge should be shared with the $\mathrm{R} \& \mathrm{D}$ unit because it is crucial for developing new products. Introduced new products are expected to meet customers' needs and preferences to a greater extent and, as a consequence, increase customer satisfaction. Empirical studies in this area, although scarce, seem to support the above reasoning. Law \& Ngai (2008) found that knowledge sharing and learning behaviors practiced by a firm contributed positively to its product and service offerings, which in turn improved organizational performance. In their study one of organizational performance measures was customer satisfaction with the purchased products or services. In light of the above reasoning, the following hypothesis is stated:

Hypothesis 4. A firm's innovativeness mediates the relationship between knowledge sharing and customer satisfaction in SMEs.

\section{Method}

\section{Data collection and sample description}

The research is based on survey data and a quantitative methodological approach to test hypotheses $\mathrm{H} 1$ to H4. A pilot questionnaire was tested on a sample of 10 managers of SMEs in January and February of 2015. Data for the main survey was collected in the first and second quarter of 2015 among SMEs associated in the Employers' Organization of Polish Copper and from the SMEs that collaborated with them but were not members of the organization. The questionnaire was intended for top managers or owners of SMEs only, because they can be viewed as the most suitable persons for questions regarding such concepts as knowledge sharing, a firm's innovativeness and customer satisfaction. Moreover, micro enterprises were excluded from the study in an effort to reduce heterogeneity within the sample. A 
total of 120 valid responses (from 120 SMEs) were received.

The SMEs came from different sectors, including services (63.3\%); sales (22.5\%); and manufacturing (14.2 $\%$ ). Most of the investigated SMEs, $69.2 \%$, have between 10 and 50 employees, whereas $30.8 \%$ of SMEs employs between 51 and 249 people. Regarding the age of firms, 54.2 $\%$ of firms are up to 10 years old, $25.8 \%$ are between 11 and 20 years old, and $20 \%$ are over 20 years old. The respondents were top managers $(62.5 \%)$ and owners/coowners $(37.7 \%)$.

\section{Data Analysis}

The stated in this study hypotheses were tested using partial least squares path modelling (PLS-PM), a variancebased method of structural equation modelling. In this study, PLS is an appropriate technique for the following reasons (Roldan \& Sanchez-Franco, 2012): PLS can estimate path models with small samples (in the present study the sample includes 120 SMEs), does not impose any distributional assumptions for measurable variables, and can be applied in both exploratory and confirmatory research. The software used for the PLS analysis was plspm package (Sanchez, 2013) that is a part of the open source project R.

\section{Measures}

Items used to measure knowledge sharing, innovativeness and customer satisfaction were gathered from the literature and suitably adapted. In this study, all of the constructs are reflective. This means that items are evoked by the corresponding constructs. Reflective indicators are assumed to be correlated and measure the same underlying construct (Chin, 1998). All measures were assessed with seven-point Likert scales, ranging from $1=$ strongly disagree to $7=$ strongly agree .

Knowledge sharing was measured using six items modified from Darroch (2003), Wong \& Aspinwall (2005), Wang et al. (2009), and Zack et al. (2009). To measure firms' innovativeness, three items were adapted from Kmieciak et al. (2012) and Wang \& Ahmed (2004). The measurement of customer satisfaction used an adaptation of the scale appearing in Lin (2014) and Lin (2015) and was modelled as a reflective construct with three indicators. Additionally, firm size was used as a control variable.

\section{Results}

The PLS path modelling is conducted in two stages: (1) the assessment of the measurement model, and (2) the evaluation of the structural model.

\section{Evaluation of measurement model}

The assessment of the measurement model involves assessing reliability and validity of constructs (Hair et al., 2011). Three aspects were evaluated: unidimensionality of the indicators, loadings, and cross-loadings. Cronbach's alpha (hereafter C.alpha), Dillon-Goldstein's rho (DG.rho), and the first and second eigenvalue (eig.1st and eig.2nd respectively) of the indicators' correlation matrix were calculated in order to check block unidimensionality (Table 1). Constructs' average variance extracted (AVE) was calculated to test the convergent validity. Additionally, to test the discriminant validity, the square root of the AVE was calculated.

Measurement Model Evaluation Results

\begin{tabular}{|c|c|c|c|c|c|c|}
\hline Construct/Item & Loading & C.alpha & DG.rho & eig.1st & eig.2nd & AVE \\
\hline Knowledge sharing (KS) & & 0.89 & 0.92 & 3.93 & 0.62 & 0.65 \\
\hline Employees share knowledge and experience by talking to each other. & 0.777 & & & & & \\
\hline $\begin{array}{l}\text { There are appropriate conditions for sharing information and knowledge between } \\
\text { employees in our firm. }\end{array}$ & 0.831 & & & & & \\
\hline Employees focus on the optimal use of available knowledge resources in the firm. & 0.818 & & & & & \\
\hline Needed information is shared and exchanged in our firm. & 0.856 & & & & & \\
\hline $\begin{array}{l}\text { Employees are co-responsible for learning and sharing knowledge in situations requiring } \\
\text { action in a different way than previously. }\end{array}$ & 0.806 & & & & & \\
\hline Asking questions is highly valued in our firm. & 0.755 & & & & & \\
\hline Innovativeness (I) & & 0.84 & 0.90 & 2.27 & 0.44 & 0.76 \\
\hline The number of introduced innovations or improvements is higher than last year. & 0.889 & & & & & \\
\hline The number of new products or services is higher than last year. & 0.878 & & & & & \\
\hline New products and services in our company often put us up against competitors. & 0.842 & & & & & \\
\hline Customer satisfaction (CS) & & 0.76 & 0.86 & 2.03 & 0.55 & 0.68 \\
\hline Customer satisfaction is higher than last year. & 0.852 & & & & & \\
\hline The number of customers is higher than last year. & 0.773 & & & & & \\
\hline The response time for customers' complaints is shorter than last year. & 0.840 & & & & & \\
\hline
\end{tabular}


Anna Michna. The Mediating role of Firm Innovativeness in the Relationship between Knowledge Sharing and Customer...

Table 2

Descriptive Statistics, Construct Correlations and Square Root of Average Variance Extracted

\begin{tabular}{|l|l|c|c|c|c|c|}
\hline & & Mean & SD & 1. & 2. & 3. \\
\hline 1. & Knowledge sharing (KS) & 5.28 & 1.08 & $\mathbf{0 . 8 0 8}$ & & \\
\hline 2. & Innovativeness (I) & 4.26 & 1.41 & $0.381 *$ & $\mathbf{0 . 8 6 9}$ & \\
\hline 3. & Customer satisfaction (CS) & 4.55 & 1.17 & $0.405^{*}$ & $0.641^{*}$ & $\mathbf{0 . 8 2 2}$ \\
\hline
\end{tabular}

Note: *Correlation significant at: $\mathrm{p}<0.05$. Diagonal elements (numbers in boldface) indicate the square root of the AVE.

As shown in Table 1, all indices exceed the recommended thresholds: C.alpha > 0.7; DG.rho > 0.7; eig.1st > 1; eig.2nd < 1; and AVE > 0.5 (Chin, 1998; Vinzi et al., 2010; Sanchez, 2013). Moreover, the observed variable loadings exceed the 0.70 threshold. The square root of the AVE is greater than all corresponding correlations (see Table 2). Finally, the discriminant validity of the measurement model was also assessed by examining the cross-loadings of the indicators. No indicator loaded higher on another construct than it did on the construct it intended to measure. Summarizing, the measurement model demonstrated adequate reliability as well as convergent and discriminant validity.

\section{Evaluation of structural model}

Following the suggestions of Baron \& Kenny (1986) for mediation test, two structural models were analyzed. The first model demonstrates only direct relationships between knowledge sharing and innovativeness and between knowledge sharing and customer satisfaction (Figure 1). In the second model innovativeness plays a mediating role between knowledge sharing and customer satisfaction (Figure 2).
The $\mathrm{R}^{2}$ determination coefficient, the redundancy index and Goodness-of-Fit (GoF) were calculated to evaluate the quality of the models (Table 3). The obtained values indicate that the quality of the second model is better than the first one. $\mathrm{R}^{2}$ for customer satisfaction in the first model was 0.222 , which is considered to be low, and increased in the second model to 0.442 , which is described as a moderate level (Sanchez, 2013). For customer satisfaction in the second model the mean redundancy is 0.299 , which can be interpreted that knowledge sharing and innovativeness predict $29.9 \%$ of the variability of the customer satisfaction indicators. The GoF index is higher in the second model (0.46) in comparison to the first one (0.37). It means that the prediction power of the second model is higher than of the first one.

In the next step, the path coefficients' statistical significance was evaluated using bootstrap validation. The bootstrap procedure enabled to generate confidence intervals $(95 \%)$ provided by the percentiles 0.025 and 0.975. As shown in Table 4, confidence interval (CI) for all path coefficients does not contain zero, therefore these coefficients are significant at a $5 \%$ confidence level (Sanchez, 2013). It means that hypotheses H1, H2 and H3 are supported.



Figure 1. Model no. 1. Direct Relationship Model

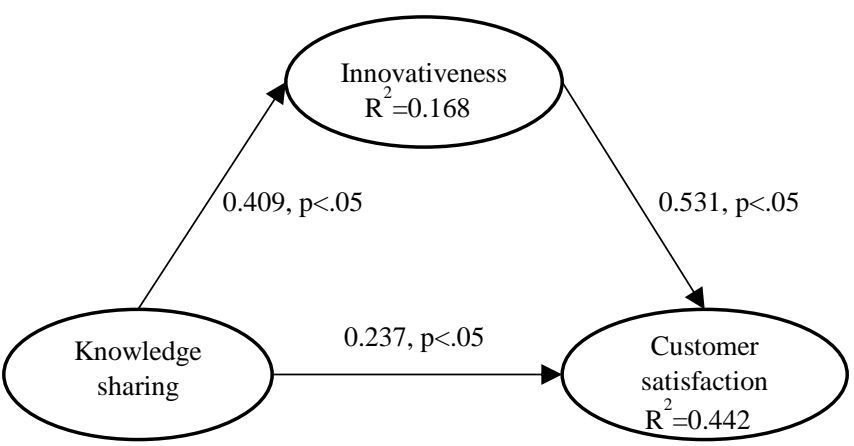

Figure 2. Model no. 2. Indirect Relationship Model 
Explained Variance, Redundancies and GoF

\begin{tabular}{|l|l|l|l|l|}
\hline & \multicolumn{2}{|c|}{ Model no. 1 } & \multicolumn{2}{c|}{ Model no. 2 } \\
\hline Variable & $\mathrm{R}^{2}$ & Mean redundancy & $\mathrm{R}^{2}$ & Mean redundancy \\
\hline Customer satisfaction & 0.222 & 0.148 & 0.442 & 0.299 \\
\hline Innovativeness & 0.173 & 0.130 & 0.168 & 0.127 \\
\hline GoF* $^{*}$ & 0.37 & 0.46 & \\
\hline
\end{tabular}

Note: *Global criterion of goodness

Structural Model Results

\begin{tabular}{|l|l|l|l|l|}
\hline & \multicolumn{3}{|c|}{ Model no. 1 } & \multicolumn{2}{c|}{ Model no. 2 } \\
\hline Path & B & Bootstrap 95\% CI & B & Bootstrap 95\% CI \\
\hline KS $\rightarrow$ CS & 0.471 & {$[0.28 ; 0.57]$ Sig. } & 0.237 & {$[0.10 ; 0.39]$ Sig. } \\
\hline KS $\rightarrow$ I & 0.415 & {$[0.32 ; 0.63]$ Sig. } & 0.409 & {$[0.27 ; 0.57]$ Sig. } \\
\hline I $\rightarrow$ CS & & & 0.531 & {$[0.38 ; 0.65]$ Sig. } \\
\hline
\end{tabular}

Note: Sig. denotes a significant direct effect at 0.05. Bootstrapping based on $n=2000$ subsamples.

To investigate whether firm's size has an impact on relationships between three constructs (knowledge sharing, innovativeness and customer satisfaction), the SMEs were divided into two groups: small (employing between 11 and 50 employees) and medium (employing between 51 and 249 employees) enterprises. Then, the bootstrap t-test and the permutation procedure were used to compare these groups (Sanchez, 2013). The obtained results indicated that the differences in path coefficients between these three constructs are not significant at a 5\% level. It can be concluded that in this study firm's size has no impact on the relationships between knowledge sharing, innovativeness and customer satisfaction.

\section{Mediation tests}

Baron \& Kenny's (1986) steps were followed to analyze mediation and to test the H4 hypothesis. First, the significant relationship between knowledge sharing (the independent variable) and innovativeness (the mediator) was found in the first model (Figure 1). Second, the significant relationship was also found between knowledge sharing (the independent variable) and customer satisfaction (the dependent variable). Third, as shown in Figure 2, innovativeness (the mediator) affects customer satisfaction (the dependent variable). It was found that the direct path coefficient between knowledge sharing and customer satisfaction declines when the indirect path through the innovativeness is created in the second model. The direct path coefficient was 0.471 and decreased to 0.237 after the introduction of innovativeness as a mediator in the second model. The amount of the decrease of the relationship between knowledge sharing and customer satisfaction accounted by the mediator was 0.234 , which represents $49.7 \%$ of the direct effect. However, the effect of knowledge sharing on customer satisfaction still exists, but in a smaller magnitude, which suggests that innovativeness partially mediates between knowledge sharing and customer satisfaction.

The significance of mediation effect was tested using bootstrapping approach (see Shrout \& Bolger, 2002). When mediation has occurred, the indirect effect should be nonzero. As shown in Table 5, none of the confident intervals contains zero, which leads to a conclusion that indirect, direct and total effect of knowledge sharing on customer satisfaction are significantly different from zero. Additionally, the variance account for (VAF) value was calculated to determine the size of the indirect effect in relation to the total effect (Hair et al., 2016). The VAF value $=48 \%$, so it is larger than $20 \%$ and less than $80 \%$, what suggests partial mediation (Hair et al., 2016). This finding confirms that innovativeness partially mediates the relationship between knowledge sharing and customer satisfaction and supports $\mathrm{H} 4$.

Table 5

Bootstrap Mediation Methods on the Effect of Knowledge Sharing on Customer Satisfaction as Mediated Through Innovativeness

\begin{tabular}{|l|c|c|c|}
\hline & \multicolumn{3}{|c|}{$95 \%$ CI } \\
\hline & Standard normal & Bootstrap percentile & Bias-corrected \\
\hline Indirect effect & {$[0.112 ; 0.315]$} & {$[0.127 ; 0.327]$} & {$[0.128 ; 0.330]$} \\
\hline Direct effect & {$[0.084 ; 0.386]$} & {$[0.098 ; 0.389]$} & {$[0.096 ; 0.387]$} \\
\hline Total effect & {$[0.290 ; 0.608]$} & {$[0.290 ; 0.612]$} & {$[0.270 ; 0.589]$} \\
\hline
\end{tabular}




\section{Discussion and Conclusion}

This study has empirically supported the hypotheses that knowledge sharing and SMEs innovativeness are positively related to customer satisfaction ( $\mathrm{H} 1$ and $\mathrm{H} 3)$. These findings confirm previous assumptions that knowledge sharing (Gupta, 2008, Supyuenyong \& Swierczek, 2011) and innovativeness (Luo \& Bhattacharya, 2006; Kibbeling et al., 2013; Rubera \& Kirca, 2017) are vital for customer satisfaction. However, in this study knowledge sharing and a firm's innovativeness predict only $29.9 \%$ of the variability of customer satisfaction indicators. It can be interpreted that there are also other important factors, except knowledge sharing and firm's innovativeness, that have a significant impact on customer satisfaction.

This study has also demonstrated that improvements in knowledge sharing contribute to better firm's innovativeness (H2), which is consistent with prior research (Lin, 2007; Chen et al., 2010; Gunu \& Ajayi, 2015). Moreover, this study fulfils research gap by giving evidence that knowledge sharing not only impacts customer satisfaction directly, but also indirectly through a firm's innovativeness (H4). In other words, the results of the mediation analysis show that a firm's innovativeness partially mediates the relationship between knowledge sharing and customer satisfaction in SMEs. This findings is consistent with previous observations that knowledge sharing is positively associated with firm operational performance either directly or via innovation (Wang \& Wang, 2012).

Despite of the underlying importance of knowledge sharing, firm's innovativeness and customer satisfaction for contemporary firms, the relationships between these constructs are less than evident in prior research focused on SMEs. Therefore, theoretical contribution of this study is the integration of separate research streams and linking together knowledge sharing, firm's innovativeness and customer satisfaction in SMEs.

There are also significant practical implications that emerge from this study. The results of this study may help managers to make non-programmable decisions including decisions related to innovativeness and introducing innovations, which are inseparably connected with management (Meczynska et al., 2013). The findings reveal that knowledge sharing appears to be an important drive of both customer satisfaction and firm's innovativeness. Hence, to improve customer satisfaction and a firm's innovativeness, managers should foster increased knowledge flows. Employees should share their knowledge and experiences when the organizational goal is to improve customer satisfaction and introduce innovative processes, products and services. To develop innovations, mangers should encourage employees to share both tacit and explicit knowledge with each other (Brzostek \& Michna, 2016a; Brzostek \& Michna, 2016b), and for this purpose managers can use such means as for example: networking, gettogethers, organized social events, mentoring and training sessions, and dialogue (Yang, 2009). Those recommendations are particularly important taking into account that in SMEs knowledge management processes, including knowledge sharing, are often unaware and informal (Kmieciak \& Michna, 2012), and "managers in smaller firms tend to prevent the outflow of knowledge from the company and thereby block knowledge sharing" (Durst \& Edvardsson, 2012, p. 881). Moreover, employees should be encouraged to absorb external knowledge to be able to respond to new and changing customers' needs, expectations and preferences.

This study has some limitations which are openings for future studies. First, this study was conducted in Poland among 120 SMEs. The business environment and consumer characteristics may differ significantly in different countries and cultures. Therefore, the specific geographical context and the size of the sample limit the generalizability of the present findings. It would be useful to replicate this study in different countries and using a larger sample size. Second, the data is self-reported and the responses were received from only one informant from every SME. Future research may adopt more objective measures such as a number of introduced innovations or customer record data from the SMEs. Finally, the research design is cross-sectional and the causal relationships cannot be proven. A longitudinal study could examine causality in more detail and show how customer satisfaction, firm's innovativeness and knowledge sharing change over time.

\section{References}

Anderson, E. W., Fornell, C., \& Lehmann, D. R. (1994). Customer Satisfaction, Market Share, and Profitability: Findings from Sweden. The Journal of Marketing, 58(3), 53-66. https://doi.org/10.2307/1252310

Andreeva, T., \& Kianto, A. (2012). Does Knowledge Management Really Matter? Linking Knowledge Management Practices, Competitiveness and Economic Performance. Journal of Knowledge Management, 16(4), 617-636. https://doi.org/10.1108/13673271211246185

Baron, R. M., \& Kenny, D. A. (1986). The Moderator-Mediator Variable Distinction in Social Psychological Research: Conceptual, Strategic and Statistical Considerations. Journal of Personality and Social Psychology, 51(6), 1173-1182. https://doi.org/10.1037/0022-3514.51.6.1173

Belas, J., \& Gabcova, L. (2016). The Relationship among Customer Satisfaction, Loyalty and Financial Performance of Commercial Banks. E \& M Ekonomie a Management, 19(1), 132-147. https://doi.org/10.15240/tul/001/2016-1-010

Benito-Bilbao, J., Sanchez-Fuente, F., \& Otegi-Olaso, J. R. (2015). Mapping the Connection between Knowledge Transfer and Firm Competitiveness: An Empirical Research in the Basque Country. Journal of Technology Management \& Innovation, 10(4), 45-56. https://doi.org/10.4067/S0718-27242015000400005 
Blut, M., Frennea, C. M., Mittal, V., \& Mothersbaugh, D. L. (2015). How Procedural, Financial and Relational Switching Costs Affect Customer Satisfaction, Repurchase Intentions, and Repurchase Behavior: A Meta-analysis. International Journal of Research in Marketing, 32(2), 226-229. https://doi.org/10.1016/j.ijresmar.2015.01.001

Boston Consulting Group (2009). Innovation 2009. The need for action: A BCG Senior Management Survey. Boston: Boston Consulting Group.

Brzostek, K., \& Michna, A. (2016a). Empirical Research on the Relationship Between Knowledge Management, Market Orientation and Small and Medium-Sized Enterprises Performance - Selected Preliminary Results. Proceedings of the 4th International Conference Innovation Management, Entrepreneurship and Corporate Sustainability, May 26-27, 2016, Prague, Czech Republic, 66-76.

Brzostek, K., \& Michna, A. (2016b). Empirical Studies Concerning the Relationship Between Knowledge Management and Effective Performance in Small and Medium-Sized Enterprises - Selected Preliminary Results. In K. Wach, \& A. Żur (Eds.), Advancing Research in Entrepreneurship in the Global Context: Conference Proceedings of the 8th ENTRE Conference, April 7-8, 2016, Cracow, Poland, 67-78.

Calantone, R. J., Chan, K., \& Cui, A. S. (2006). Decomposing Product Innovativeness and Its Effects on New Product Success. Journal of Product Innovation Management, 23(5), 408-421. https://doi.org/10.1111/j.15405885.2006.00213.x

Castaneda, J. A. (2011). Relationship Between Customer Satisfaction and Loyalty on the Internet. Journal of Business and Psychology, 26(3), 371-383. https://doi.org/10.1007/s10869-010-9196-Z

Chen, C. J., Huang, J. W., \& Hsiao, Y. C. (2010). Knowledge Management and Innovativeness. The role of Organizational Climate and Structure. International Journal of Manpower, 31(8), 848-870. https://doi.org/10.1108/ 01437721011088548

Chin, W. W. (1998). The partial least squares approach to structural equation modeling. In G. A. Marcoulides (Ed.), Modern methods for business research (pp. 295-336). Mahwah, NJ: Lawrence Erlbaum Associates.

Darroch, J. (2003). Developing a Measure of Knowledge Management Behaviors and Practices. Journal of Knowledge Management, 7(5), 41-54. https://doi.org/10.1108/13673270310505377

Darroch, J., \& McNaughton, R. (2002). Examining the Link between Knowledge Management Practices and Types of Innovation. Journal of Intellectual Capital, 3(3), 210-222. https://doi.org/10.1108/14691930210435570

Demirci Orel, F., \& Kara, A. (2014). Supermarket Self-Checkout Service Quality, Customer Satisfaction, and Loyalty: Empirical Evidence from an Emerging Market. Journal of Retailing and Consumer Services, 21(2), 118-129. https://doi.org/10.1016/j.jretconser.2013.07.002

Diaz, G. R. (2017). The Influence of Satisfaction on Customer Retention in Mobile Phone Market. Journal of Retailing and Consumer Services, 36, 75-85. https://doi.org/10.1016/j.jretconser.2017.01.003

Dongmo, C., \& Onojaefe, D. (2013). Using Customer Satisfaction to Understand Implementation Benefits of the ISO 9001 Quality Management System, Business Management Dynamics, 3(3), 1-9. http://hdl.handle.net/11189/2164

Durst, S., \& Edvardsson, I. R. (2012). Knowledge Management in SMEs: A Literature Review. Journal of Knowledge Management, 16(6), 879-903. https://doi.org/10.1108/13673271211276173

Gloor, P., Fronzetti Colladon, A., Giacomelli, G., Saran, T., \& Grippa, F. (2017). The Impact of Virtual Mirroring on Customer Satisfaction. Journal of Business Research, 75, 67-76. https://doi.org/10.1016/j.jbusres.2017.02.010

Gunu, U., \& Ajayi, O. (2015). Knowledge Sharing and Firm Innovativeness in Food Industry in South-Western Nigeria. Global Management Review, 9(4), 46-65.

Gupta, K. S. (2008). A Comparative Analysis of Knowledge Sharing Climate. Knowledge and Process Management, 15(3), 186-195. https://doi.org/10.1002/kpm.309

Hair, J. F., Hult, G. T. M., Ringle, C. M., \& Sarstedt, M. (2016). A primer on Partial Least Squares Structural Equation Modeling (PLS-SEM). Thousand Oaks, CA: Sage.

Hair, J. F., Ringle, C. M. \& Sarstedt, M. (2011). PLS-SEM: Indeed a Silver Bullet. Journal of Marketing Theory and Practice, 19(2), 139-152. https://doi.org/10.2753/MTP1069-6679190202

Haverila, M. J., \& Fehr, K. (2016). The Impact of Product Superiority on Customer Satisfaction in Project Management. International Journal of Project Management, 34(4), 570-583. https://doi.org/10.1016/j.ijproman.2016.02.007 
Anna Michna. The Mediating role of Firm Innovativeness in the Relationship between Knowledge Sharing and Customer...

Helgesen, O. (2006). Are Loyal Customers Profitable? Customer Satisfaction, Customer (Action) Loyalty and Customer Profitability at the Individual Level. Journal of Marketing Management, 22(3/4), $245-266$. https://doi.org/10.1362/026725706776861226

Hennart, J. F. (2014). The Accidental Internationalists: A Theory of Born Globals. Entrepreneurship: Theory \& Practice. 38(1), 117-135. https://doi.org/10.1111/etap.12076

Homburg, C., \& Stock, R. M. (2004). The Link between Sales People's Job Satisfaction and Customer Satisfaction in a Business-To-Business Context: A Dyadic Analysis. Journal of the Academy of Marketing Sciences, 32(2), $144-158$. https://doi.org/10.1177/0092070303261415

Homburg, C., Koschate, N. \& Hoyer, W. (2005). Do Satisfied Customers Really Pay More? A Study of the Relationship between Customer Satisfaction and Willingness to Pay. Journal of Marketing, 69, 84-96. https://doi.org/10.1509/jmkg.69.2.84.60760

Hudson, M., Smart, A., \& Bourne, M. (2001). Theory and practice in SME performance measurement systems. International Journal of Operations and Production Management, 21(8), 1096-1115. https://doi.org/10.1108/EUM0000000005587

Hult, G. T. M., Hurley, R. F., \& Knight, G. A. (2004). Innovativeness, Its Antecedents and Impact on Business Performance. Industrial Marketing Management, 33(5), 429-438. https://doi.org/10.1016/j.indmarman.2003.08.015

Ipe, M. (2003). Knowledge Sharing on Organizations: A Conceptual Framework. Human Resource Development Review, 2(4), 337-359. https://doi.org/10.1177/1534484303257985

Kasiri, L. A., Guan Cheng, K. T., Sambasivan, M., \& Sidin, S. M. (2017). Integration of standardization and customization: impact on service quality, customer satisfaction, and loyalty. Journal of Retailing and Consumer Services, 35, 91-97. https://doi.org/10.1016/j.jretconser.2016.11.007

Kibbeling, M., van der Bij, H., \& van Weele, A. (2013). Market Orientation and Innovativeness in Supply Chains: Supplier's Impact on Customer Satisfaction. Journal of Product Innovation Management, 30(3), 500-515. https://doi.org/10.1111/jpim.12007

Kmieciak, R., \& Michna, A. (2012). Relationship Between Knowledge Management and Market Orientation in SMEs. Proceedings of the Management, Knowledge and Learning International Conference (MakeLearn) 2012 Knowledge and Learning: Global Empowerment, June 20-22, 2012, Celje, Slovenia, 175-183.

Kmieciak, R., Michna, A. \& Meczynska, A. (2012). Innovativeness, Empowerment and IT Capability: Evidence from SMEs. Industrial Management \& Data Systems, 112(5), 707-728. https://doi.org/10.1108/02635571211232280

Kotler, P., Keller, K., Brady, M., Goodman, M., \& Hansen, T. (2009). Marketing Management. Harlow: Pearson Education Limited.

Krajnakova, E., Navikaite, A., \& Navickas, V. (2015). Paradigm Shift of Small and Medium-Sized Enterprises Competitive Advantage to Management of Customer Satisfaction. Inzinerine Ekonomika-Engineering Economics, 26(3), $327-332$. https://doi.org/10.5755/j01.ee.26.3.6608

Law, C. C. H., \& Ngai, E. W. T. (2008). An Empirical Study of the Effects of Knowledge Sharing and Learning Behaviors on Firm Performance. Expert Systems with Applications, 34(4), 2342-2349. https://doi.org/10.1016/ j.eswa.2007.03.004

Lee J., \& Lee, H. (2013). Does Satisfaction Affect Brand Loyalty? Academy of Marketing Studies Journal, 17(2), $133-147$.

Lin, H. F. (2007). Knowledge Sharing and Firm Innovation Capability: An Empirical Study. International Journal of Manpower, 28(3/4), 315-332. https://doi.org/10.1108/01437720710755272

Lin, H. F. (2014). A Multi-Stage Analysis of Antecedents and Consequences of Knowledge Management Evolution. Journal of Knowledge Management, 18(1), 52-74. https://doi.org/10.1108/JKM-07-2013-0278

Lin, H. F. (2015). Linking Knowledge Management Orientation to Balanced Scorecard Outcomes. Journal of Knowledge Management, 19(6), 1224-1249. https://doi.org/10.1108/JKM-04-2015-0132

Liua, Y., \& Phillips, J. S. (2011). Examining the Antecedents of Knowledge Sharing in Facilitating Team Innovativeness from a Multilevel Perspective. International Journal of Information Management, 31(1), https://doi.org/10.101 6/j.ijinfomgt.2010.05.002

Lumpkin, G. T., \& Dess, G. G. (1996). Clarifying the Entrepreneurial Orientation Construct and Linking It to Performance. Academy of Management Journal, 21(1), 135-172. https://doi.org/10.5465/AMR.1996.9602161568

Luo, X., \& Bhattacharya, C. B. (2006). Corporate Social Responsibility, Customer Satisfaction, and Market Value. Journal of Marketing, 70, 1-18. https://doi.org/10.1509/jmkg.70.4.1 
Meczynska, A., Kmieciak, R., Michna, A., \& Flajszok, I. (2013). A decision support method for poorly structured problems in school management. Baltic Journal of Management, 9(1), 91-112. https://doi.org/10.1108/BJM-04-2013-0058

Michna, A., Kmieciak, R., \& Burzynska-Ptaszek, K. (2017). Job preferences and expectations of disabled people and small and medium-sized enterprises in Poland: Implications for disabled people's professional development. Human Resource Development Quarterly, 28(3), 299-336. https://doi.org/10.1002/hrdq.21280

Nawrocki, T., \& Jonek-Kowalska, I. (2016). Fuzzy Approach to Corporate Potential Innovativeness Assessment. Proceedings of the International Conference on Management: Trends of management in the contemporary society. June 9-10, 2016, Brno, Czech Republic, 321-324.

Oliver, R. L. (1997). Satisfaction: A Behavioral Perspective on the Consumer. Boston, MA: Irwin McGraw-Hill.

Oliver, R. L., Rust, R. T., \& Varki, S. (1997). Customer Delight: Foundations, Findings, and Managerial Insight. Journal of Retailing, 73(3), 311-336. https://doi.org/10.1016/S0022-4359(97)90021-X

Roldan, J. L., \& Sanchez-Franco, M. J. (2012). Variance-based structural equation modelling: guidelines for using partial least squares in information systems research. In M. Mora (Ed.), Research methodologies, innovations and philosophies in software systems engineering and information systems (pp. 193-221). Hershey, PA: IGI Global. https://doi.org/10.4018/978-1-4666-0179-6.ch010

Rubera, G., \& Kirca, A. H. (2017). You Gotta Serve Somebody: the Effects of Firm Innovation on Customer Satisfaction and Firm Value. Journal of the Academy of Marketing Science, 45(5), 741-761. https://doi.org/10.1007/s11747-016-0512-7

Ryu, S., Ho, S. H., \& Han, I. (2003). Knowledge Sharing Behavior of Physicians in Hospitals. Expert Systems with Applications, 25 (1), 113-122. https://doi.org/10.1016/S0957-4174(03)00011-3

Sanchez, G. (2013). PLS Path Modeling with R. Berkeley: Trowchez Editions.

Serenko, A., \& Bontis, N. (2016). Negotiate, Reciprocate, or Cooperate? The Impact of Exchange Modes on Inter-Employee Knowledge Sharing. Journal of Knowledge Management, 20(4), 687-712. https://doi.org/10.1108/JKM-10-2015-0394

Shrout, P. E., \& Bolger, N. (2002). Mediation in Experimental and Nonexperimental Studies: New Procedures and Recommendations. Psychological Methods, 7(4), 422-445. https://doi.org/10.1037//1082-989X.7.4.422

Sok, P., O'Cass, A., \& Miles, M. P. (2016). The Performance Advantages for SMEs of Product Innovation and Marketing Resource-Capability Complementarity in Emerging Economies. Journal of Small Business Management, 54(3), 805826. https://doi.org/10.1111/jsbm.12172

Spreng, R., MacKenzie, S., \& Olshavsky, R. (1996). Re-examination of the Determinants of Consumer Satisfaction. Journal of Marketing, 60(3), 15-35. https://doi.org/10.2307/1251839

Srivastava, K., \& Sharma, N. K. (2013). Service Quality, Corporate Brand Image, and Switching Behavior: The Mediating Role of Customer Satisfaction and Repurchase Intention. Services Marketing Quarterly, 34(4), 274-291. https://doi.org/10.1080/15332969.2013.827020

Steward, M. D. (2008). Intraorganizational Knowledge Sharing among Key Account Salespeople: The Impact on Buyer Satisfaction. The Marketing Management Journal, 18(2), 65-75.

Stock, R. M. (2011). How Does Product Program Innovativeness Affect Customer Satisfaction? A Comparison of Goods and Services. Journal of the Academy of Marketing Science, 39(6), 813-827. https://doi.org/10.1007/s11747-010-0215-4

Supyuenyong, V., \& Swierczek, F. W. (2011). Knowledge Management Process and Organizational Performance in SMEs. International Journal of Knowledge Management, 7(2), 1-21. https://doi.org/10.4018/jkm.2011040101

Theoharakis, V., \& Hooley, G. (2008). Customer Orientation and Innovativeness: Differing Roles in New and Old Europe. International Journal of Research in Marketing, 25(1), 69-79. https://doi.org/10.1016/j.ijresmar.2007.09.007

Vinzi, V. E., Trinchera, L., \& Amato, S. (2010). PLS path modeling: from foundations to recent developments and open issues for model assessment and improvement. In V. E. Vinzi, W. W. Chin, J. Henseler \& H. Wang (Eds.), Handbook of Partial Least Squares: Concepts, Methods, and Applications (pp. 47-82). Heidelberg: Springer. https://doi.org/10.1007/978-3540-32827-8_3

Wang, C. L., Hult, G. T. M., Ketchen, D. J., \& Ahmed, P. K. (2009). Knowledge Management Orientation, Market Orientation, and Firm Performance: An Integration And Empirical Examination. Journal of Strategic Marketing, 17(2), 147-170. https://doi.org/10.1080/09652540902879326

Wang, C. L., \& Ahmed, P. K. (2004). The Development and Validation of the Organizational Innovativeness Construct Using Confirmatory Factor Analysis. European Journal of Innovation Management, 7(4), 303-313. https://doi.org/10. $1108 / 14601060410565056$ 
Anna Michna. The Mediating role of Firm Innovativeness in the Relationship between Knowledge Sharing and Customer...

Wang, Z., \& Wang, N. (2012). Knowledge sharing, innovation and firm performance. Expert Systems with Applications, 39(10), 8899-8908. https://doi.org/10.1016/j.eswa.2012.02.017

Wong, K. Y., \& Aspinwall, E. (2005). An Empirical Study of the Important Factors for Knowledge-Management Adoption in the SME Sector. Journal of Knowledge Management, 9(3), 64-82. https://doi.org/10.1108/13673270510602773

Yang, J. T. (2009). Individual Attitudes to Learning and Sharing Individual and Organizational Knowledge in the Hospitality Industry. The Service Industries Journal, 29(12), 1723-1743. https://doi.org/10.1080/02642060902793490

Zack, M., McKeen, J., \& Singh, S. (2009). Knowledge Management and Organizational Performance: An Exploratory Analysis. Journal of Knowledge Management, 13(6), 392-409. https://doi.org/10.1108/13673270910997088

Zieba, M., \& Zieba, K. (2014). Knowledge Management Critical Success Factors and the Innovativeness of KIBS Companies. Inzinerine Ekonomika-Engineering Economics, 25(4), 458-465. https://doi.org/10.5755/j01.ee.25.4.6494

The article has been reviewed.

Received in September, 2017; accepted in February, 2018. 